\title{
Human Cultural Evolution: Postmodernity as Rational Global Diversity
}

\author{
Dingyu Chung \\ Utica, MI, USA \\ Email: dy_chung@yahoo.com
}

How to cite this paper: Chung, D.Y. (2017) Human Cultural Evolution: Postmodernity as Rational Global Diversity. Open Journal of Social Sciences, 5, 304-337. https://doi.org/10.4236/jss.2017.55022

Received: March 28, 2017

Accepted: May 20, 2017

Published: May 23, 2017

Copyright $\odot 2017$ by author and Scientific Research Publishing Inc. This work is licensed under the Creative Commons Attribution International License (CC BY 4.0).

http://creativecommons.org/licenses/by/4.0/

\begin{abstract}
This paper proposes that human culture has evolved from authoritative local premodernity through rational local modernity to the coming rational global postmodernity with diverse cultural types. Premodernity, modernity, and postmodernity are the cultural adaptations to the drastic social changes from the Agricultural, Industrial, and Information Revolutions. The cultural types analogous to biological species are the nine cultural types derived from the instinctive cultural type model based on the instinctive sociality trichotomy (individualistic, collectivistic, and interdependent) and the instinctive worldview trichotomy (territorial, connective, and competitive). Western culture originated from the Middle East and Greece has competitive worldview, while Eastern culture originated from India and China has connective worldview. Different cultural types have different perceptions, moralities, religions, politics, and economies. Currently, the world is the chaotic diverse global society where the cultural types clash. The coming postmodernity as rational global diversity is produced by the three rational global diverse systems. The rational global diverse system for the coming postmodern international politics is the three-tier international politics consisting of nations with geopolitical boundaries, the 12 regional communities with cultural-geographic boundaries, and the global international organizations without boundary. The rational global diverse system for the coming postmodern international trade is the trichotomic international trade containing free competitive, free connective, and fair protectionist international trades. The rational global diverse system for the coming postmodern common ground between religion and science is the cultural theology of trinity consisting of the transcendental, immanent, and imaginary cultural origins. The coming postmodernity as rational global diversity will bring rational order and peace among global diverse cultural types.
\end{abstract}

\section{Keywords}

Human Cultural Evolution, Postmodernity, Modernity, Premodernity, 
Instinctive Cultural Type Model, Rational Global Diversity, Worldview,

Sociality, Great Apes, Three-Tier International Politics, Regional Community, Trichotomic International Trade, Cultural Theology of Trinity

\section{Introduction}

The three principles of biological evolution are variation, selection, and inheritance. Similarly, cultural evolution also has such three principles [1]. In biological evolution, variation, selection, and inheritance correspond to the stages in biological evolution, the biological adaptations to drastic environmental changes, and biological species, respectively. Similarly, in cultural evolution, variation, selection, and inheritance correspond to the stages in cultural evolution, the cultural adaptations to drastic social changes, and cultural types, respectively. Biological species in biological evolution correspond to cultural types in cultural evolution. In this paper, the three stages in the human cultural evolution are premodernity, modernity, and postmodernity. These three stages are the cultural adaptations to the drastic social changes from the Agricultural, Industrial, and Information Revolutions. The cultural types in the human cultural evolution are the nine cultural types derived from the instinctive cultural type model based on the instinctive sociality trichotomy (individualistic, collectivistic, and interdependent) and the instinctive worldview trichotomy (territorial, connective, and competitive) as described in the previous papers [2] [3]. The instinctive cultural type model is the group social behavior model for advanced social animals. As described in this paper, Western culture originated from the Middle East and Greece has competitive worldview, while Eastern culture originated from India and China has connective worldview. As pointed out by Michael Karlberg in the book "Beyond the Culture of Contest", Western culture is essentially the culture of contest [4]. According to Nisbett and Yuki, the perceptions of Western culture and Eastern culture are fundamentally different [5] [6]. The different cultural types from the nine cultural types have different perceptions, moralities, religions, politics, and economies.

There are many definitions of premodernity, modernity, and postmodernity. In this paper, premodernity, modernity, and postmodernity are defined by the source, size, and content of culture. The source of culture can be authoritative tradition or rational system. Authoritative tradition is an unquestionable tradition from the past. Rational system is a logical, consistent, demonstrable, factual, and provable system. Human capacity of reasoning in the frontal lobe of the neocortex for the rational brain allows human society to develop rational system. Authoritative tradition is to be followed literally, while rational system is to be questioned continuously. The size of culture can be small local, large local, or global. The content of culture can be homogeneous with one cultural type, or can be diverse with multiple cultural types. For animals and premodern humans, the source of culture is mostly authoritative tradition from old generation to 
pass to new generation under the same environment. Originally, human society was a small local society which had cultural homogeneity with one cultural type. As a result, premodernity is defined as authoritative local homogeneity.

The biological adaptation to drastic environmental changes is the major force in biological evolution. Similarly, the cultural adaptation to drastic social changes is the major force in the human cultural evolution. One of the drastic social changes resulted from the Agricultural Revolution which changed premodern small local society with one authoritative tradition into large local society with multiple authoritative traditions. The conflicting authoritative traditions resulted in the clash of authoritative traditions to produce the chaotic large local society within one cultural type. Authoritative tradition could no longer be the dominant base of integral large society, and was replaced by rational system, which transformed the chaotic large society into the orderly rational large society within one cultural type. Modernity is defined as rational local homogeneity. In the West, a founder of modernity is Rene Descartes (1596-1650) who promoted independent reason ( $\mathrm{I}$ think, therefore I am) instead of authoritative tradition as the starting point of knowledge. According to Max Weber, modernity is directly related to rationality [7].

The other drastic social-environmental changes have resulted from the Industrial and the Information Revolutions which cause globalization with increasing global interdependence in terms of division of labor and resource. Today, very few products are manufactured entirely in a single country, and people consume products daily from all over the world. The Industrial and Information Revolutions change modern large local society into global society containing different cultural types. The conflicting cultural types bring about the cultural clash. The cultural clash results in the chaotic diverse global society with chaotic global diversity. Currently, the world is the chaotic diverse global society.

This paper proposes that the chaotic diverse global society can be transformed into the orderly rational diverse global society by the rational global diverse systems, bringing about the coming postmodernity with multiple cultural types. Postmodernity is defined as rational global diversity. In this paper, the proposed rational global diverse systems for the coming postmodernity consist of the nine cultural types from the instinctive cultural type model. The proposed rational global diverse system for the coming postmodern international politics is the three-tier international politics consisting of nations with geopolitical boundaries, the 12 regional communities with cultural-geographic boundaries, and the global international organizations without boundary. The rational global diverse system for the coming postmodern international trade is the trichotomic international trade containing free competitive, free connective, and fair protectionist international trades. The rational global diverse system for the coming postmodern common ground between religion and science is the cultural theology of trinity consisting of the transcendental, immanent, and imaginary cultural origins. The coming postmodernity as rational global diversity will bring rational order and peace among global diverse cultural types. 
This paper proposes that human culture has evolved from authoritative local premodernity through rational local modernity to the coming rational global postmodernity with diverse cultural types. Premodernity, modernity, and postmodernity are defined as authoritative local homogeneity, rational local homogeneity, and rational global diversity, respectively. Section 2 describes the cultural types derived from the instinctive cultural type model, and the cultural types for the great apes. The Sections 3 describes the human cultural evolution of the cultural types through the five periods (the Secular Prehistoric, Religious Prehistoric, Agricultural-Nomadic, Industrial, and Information) and the three stages (premodernity, modernity, and postmodernity). To bring about the coming postmodern, the rational global diverse systems are the three-tier international politics, the trichotomic international trade, and the cultural theology of trinity.

\section{The Instinctive Cultural Type Model and the Great Apes}

In the human cultural evolution, the cultural types correspond to biological species in biological evolution. This section describes the nine cultural types derived from the instinctive cultural type model, and the cultural types for the great apes. The instinctive cultural type model is the group social behavior model for advanced social animals. The instincts are derived from the biological adaptations to environment in social evolution. The instinctive cultural type model has nine cultural types based on the instinctive sociality trichotomy (individualistic, collectivistic, and interdependent) and the instinctive worldview trichotomy (territorial, connective, and competitive) [2] [3]. Instinctive sociality is the instinctive tendency to form corporative society. As described previously [2], for social animals, the instinctive sociality trichotomy consists of individualistic, collectivistic, and interdependent socialities in the order from the lowest degree of instinctive sociality to the highest degree of instinctive sociality. The degree of sociality, $S$, of individualistic sociality is zero as follows.

$$
S_{\text {individualistic }}=0
$$

Each individual is for itself without belonging to any specific stable social group. Among the great apes, the principal instinctive sociality for chimpanzees is individualistic instinctive sociality which is the instinctive sociality of dominant adult male chimpanzees. Each male adult chimpanzee is independent, and has to fight for his food and social ranking without belonging to any specific stable social group.

In collectivistic instinctive sociality, the children are vulnerable due the dependent childhood. The survival of the vulnerable children requires caregivers, forming the social group of caregivers and vulnerable children. For collectivistic instinctive sociality formula,

$$
S_{\text {collectivistic }}=n \sum_{j=1}^{m} r_{j}
$$

where $n$ is the number of vulnerable children per family group, $r_{j}$ is the relatedness coefficient as the degree of genetic relatedness between the vulnerable 
children and the caregiver, $r$ is equal to 0.5 for parent and sibling, 0.25 for uncle-aunt, and 0.25 for grandparent, and $m$ is the number of caregivers. The social group consisting of children and caregivers is kin group as described by inclusive fitness [2] [8] [9] of kin selection based on the Hamilton's Rule $(c<b r)$ whose number $(b)$ of beneficiaries corresponds to the number $(n)$ of children in Equation (2), and whose reproductive cost (c) to altruist corresponds to the reproductive cost to social group formation which is less than the degree of sociality $(S)$ when $m=1$ in Equation (2). For the great apes, the instinctive sociality of orangutan, gorillas and bonobos is collectivistic instinctive sociality. Orangutan has solitary collectivistic instinctive sociality where a mother orangutan is able to take care of her child without additional caregivers. As a result, collectivistic instinctive sociality for orangutan with mother and one child is 0.5 . Solitary collectivistic instinctive sociality requires abundant resource with low resource competition. The resource competition for gorillas and bonobos in their natural habitats is greater than the resource competition of orangutans in its natural habitat. Gorillas and bonobos require additional caregivers in kin group.

In interdependent instinctive sociality, both the children and the social group are vulnerable. The social group is vulnerable due to the vulnerable adults to exist alone. The survival of the vulnerable social group requires permanent existential interdependence in terms of permanent existential division of labor. For example, the social group of bees is vulnerable due to the vulnerable adult bees to exist alone, and the survival of the social group requires the existential division of labor. Queen bees take care of reproduction, but to survive, queen bees must receive care from infertile worker bees that work but must rely on queen bees to reproduce, resulting in the existential interdependence. Without the existential interdependence among adult bees, the social group of bees would have not been able to exist. The number of the interdependent specialist types in division of labor for bees is equal to three consisting of fertile queen bee, fertile drone bee, and infertile worker bee. For the interdependent instinctive sociality formula,

$$
S_{\text {interdependent }}=k n \sum_{j=1}^{m} r_{j}
$$

where $k$ is the number of interdependent specialist types. Interdependent instinctive sociality is normally called eusociality. Eusociality [10] is the highest level of organization of animal instinctive sociality in certain insects, crustaceans, and mammals. Ants, bees, and termites are eusocial animals.

Human is a species of eusocial ape [11]. As described previously [2], around 6 millions of years ago, a major climate change reduced some part of forested area in Africa to woodland where Ardi (Ardipithecus ramidus) [12] was evolved. Ar$\mathrm{di}$, the oldest human ancestor (4.4 million year old) discovered, lived on woodland. Similar to other apes, Ardi's skull encased a small brain 300 to $350 \mathrm{cc}$. She lived in the mixed habitat of grassy woodland with patches of denser forest and freshwater springs. The appearance of woodland caused the evolution from the 
social orangutan-like common ancestor to produce the bipedal human ancestors, the early hominins. Woodland allowed increasingly amount of food from bushes and low branches, which could be seen and reached from the ground. For reaching food from low branches on woodland and to carry food, the early hominins came down to the ground partly (not entirely) from living among trees, and adopted bipedalism as the way to move on the ground. However, Ardi's foot was primitive with an opposable big toe that could not provide a push needed for efficient bipedal walking. Ardi had a more primitive walking ability than later hominins, and Ardi had a somewhat awkward gait when on the ground. Her feet were still adapted for grasping trees rather than walking for long distances and running fast on the ground. The movement handicap of bipedalism on the ground was serious for very young, very old, and pregnant early hominins. To the early hominins in the mixed habitats, the area with many tall trees was the safe home area where very young, very old, and pregnant hominins stayed for homemaking and forage, and where they could escape quickly to the safety in tall trees, and the area with few tall trees was the unsafe exploration area for the exploration to find extra foods that could not be found in the safe home area. The vulnerability in bipedalism and the mixed habitat allowed early hominins to develop the division of interdependent labor in terms of fertile homemaker-forager, infertile homemaker-forager for females after menopause, and fertile explorer-forager. The division of labor allowed the early hominins to take full advantage of the mixed habitat in terms of security and food procurement. Without the existential interdependence, the social group of early hominins would have not been able to exist. Instinctive interdependent sociality existed from the the early hominins up to civilized humans.

As described previously [3], for social animals, instinctive worldview is derived from ingroup and outgroup. In ingroup, individuals share similar interests and attitudes, and produce instinctive feeling of ingroup favoritism as solidarity, community, and exclusivity [13]. Individuals in outgtoup outside one's own group are different in interests and attitudes, and produce instinctive feeling of outgroup derogation as inferiority and alienation. Morality is defined as proper behavior. Morality toward ingroup is opposite of morality toward outgroup [14]. Ingroup morality is cooperative connection derived from instinctive ingroup favoritism. Outgroup morality is zero-sum aggressive competition derived from mutual outgroup derogation among social groups. According to evolutionary psychologists, this discrimination between connective ingroup morality and competitive outgroup morality has evolved because it enhances group survival in terms of instinctive cooperative connection toward ingroup and instinctive aggressive competition toward outgroup [15]. Such attitudes toward ingroup and outgroup are instinctive, appearing even in babies at few months old. As shown in the Infant Cognition Center at Yale University [16], babies prefer the objects (such as dolls) as ingroup objects that have similarities with the babies rather than the objects as outgroup objects that do not have similarities with the babies. Babies also prefer the objects with helpful behavior to the objects with bully be- 
havior. However, babies prefer the doll that bullies another doll that is not like the babies. In other words, even though babies dislike the individuals who harm other individuals, babies prefer the individuals who harm outgroup individuals that are not like the babies. The zero-sum competitive attitude toward outgroup is instinctive.

When there is clear boundary with a large buffer zone between ingroup and outgroup, the instinctive worldview is territorial worldview where connective ingroup and competitive outgroup are equally important. On the other hand, when the boundary between ingroup and outgroup is unclear, and there is no large buffer zone between ingroup and outgroup, the instinctive worldview can be connective worldview or competitive worldview. For connective worldview, the whole world is virtually a connective ingroup, so connection is much more important than competition. For competitive worldview, the whole world is virtually a competitive outgroup, so competition is much more important than connection. Under the condition of unclear boundary and high resource competition, competitive worldview prevails over connective worldview, while under the condition of unclear boundary and low resource competition, connective worldview prevails over competitive worldview. The instinctive worldview trichotomy consists of instinctive competitive, connective, and territorial worldviews.

The combination of the instinctive sociality trichotomy and the instinctive worldview trichotomy constitutes the instinctive cultural type model to provide the nine different cultural types. Among the great apes, orangutan, gorilla, and prehistoric human have territorial worldview with clear boundary between ingroup and outgroup. The cultural type of orangutan and gorilla are collectivistic territorial cultural type, while prehistoric human has interdependent territorial cultural type. Chimpanzee and bonobo have fission-fusion society with overlapping social groups in which the social group size and composition change throughout the year with different activities and situations. As a result they do not have clear boundary between ingroup and outgroup. The natural habitat where chimpanzees live has much higher resource competition than the natural habitat where bonobos live. Therefore, the principal worldviews of chimpanzees and bonobos are competitive worldview and connective worldview, respectively. The instinctive sociality of adult male chimpanzees is individualistic sociality, so the cultural type is individualistic competitive cultural type as shown in the highly aggressive behaviors of individualistic adult male chimpanzees that can be described as male warriors [17]. Each adult male chimpanzee has to fight for its food and social ranking. The principal cultural type of chimpanzees is individualistic competitive cultural type from dominant male chimpanzees. On the other hand, the principal sociality of adult female bonobos is collectivistic sociality, so the cultural type is collectivistic connective cultural type as shown in highly peaceful behaviors of collectivistic female bonobos that can be described as female peacemakers. Bonobos find relationships among one another in terms of sexual interactions regardless of identities. The principal cultural type of bono- 
bos is collectivistic connective cultural type from dominant female bonobos. There are also differences in the cognitive skills of bonobos and chimpanzees [18]. The study showed that bonobos were more skilled at solving collectivistic connective tasks related to theory of mind or an understanding of social causality, while chimpanzees were more skilled at individualistic tasks requiring the use of tools and an understanding of physical causality. In summary, orangutans, gorilla, prehistoric humans, chimpanzees, and bonobos have solitary collectivistic territorial, collectivistic territorial, interdependent territorial, individualistic competitive, and collectivistic connective cultural type, respectively.

\section{The Human Cultural Evolution of the Cultural Types}

The previous section derives the cultural types from the instinctive cultural model. This section describes the human cultural evolution of the cultural types through the five periods (the Secular Prehistoric, Religious Prehistoric, Agricultural-Nomadic, Industrial, and Information) and the three stages (premodernity, modernity, and postmodernity). The nine cultural types derived from the instinctive cultural type model based on the instinctive sociality trichotomy (individualistic, collectivistic, and interdependent) and the instinctive worldview trichotomy (territorial, connective, and competitive) are individualistic territorial, collectivistic territorial, interdependent territorial, individualistic competitive, collectivistic competitive, interdependent competitive, individualistic connective, collectivistic connective, and interdependent connective cultural types. For humans, each cultural type has its own perception, morality, religion, politics, and economy. Different cultural types appear at different times and places during the human cultural evolution. The five periods of the human cultural evolution are: 1. the Secular Prehistoric Period from the beginning of Homo sapiens around 200,000 years ago to the Upper Paleolithic Revolution about 40,000 year ago; 2. the Religious Prehistoric Period as the Upper Paleolithic Period from about 40,000 to to Agricultural Revolution (Neolithic Revolution) about 10,000 year ago; 3. the Agricultural-Nomadic Period from about 10,000 years ago to the Industrial Revolution about 250 year ago; 4. the Industrial Period from 250 years ago to the Information Revolution in about 1970's; and 5. the Information Revolution from about 1970's [3]. The three stages of the evolution are premodernity, modernity, and postmodernity. Modernity appeared in the West and the East at different times.

As described in the previous section, the initial cultural type which was the cultural type for the Secular Prehistoric Period is interdependent territorial cultural type. For Homo sapiens, the division of labor consisted of fertile homemaker-gatherer mostly for younger women, infertile homemaker-gatherer mostly for older women, and fertile explorer-hunter mostly for men [2]. The moral behavior was interdependence, while immoral behavior was independence or dependence. There is no evidence for extensive religious practice during this period, so this period was secular with insignificant religious practice. The prehistoric human society may be similar to the modern Bushman in African's Ka- 
lahari Desert as described by Marshall Sahlins' "The Original Affluent Society" [19]. It is egalitarian and peaceful. The hunter-gatherer society in small groups (about 20 - 35 people) adjusts its daily needs and desires with what is available to them.

The Religious Prehistoric Period as the Upper Paleolithic Period was a very difficult cold period that prompted vulnerable humans to be dependent on the supernatural as the cultural adaptation to the drastic environmental change [3]. The supernatural was represented by the imaginary female figurines [20] and cave paintings [21]. During this harsh time, Neanderthals became extinct, because Neanderthals required about 600 or 700 calories a day more than humans to survive [22], and probably also because Neanderthals did not develop such religious symbols for the cultural adaptation to help them to survive the harsh time. The major difference between the Secular Prehistoric Period and the Religious Prehistoric Period is imagination. The concept of the supernatural as religion is derived from imaginary objects as proposed by Maurice Bloch [23], who proposed that such development of imagination occurred at about the time of the Upper Paleolithic Revolution. Imagination is beyond daily perception for survival. Imagination has been expanded rapidly to all different areas since the Upper Paleolithic Revolution. According to Maurice Bloch, imagination becomes omnipresence in human culture [3] [23].

The Agricultural Revolution (Neolithic Revolution) as the transition from hunting and gathering to the cultivated crops and domesticated animals for their subsistence was first adopted by various independent prehistoric human societies about 10,000 years ago, resulting in the Agricultural-Nomadic Period. Large cities and clans emerged. At the beginning, there were clear borders between ingroup and outgroup among the basic political units. People were clearly loyal to their city states or clans. The further advance of technology and the increase in population and wealth increased the interactions among multiple city-states/ clans, resulting in the continuous merges and splits of city-states/clans that destroyed clear boundaries. The human society was transformed from small societies with clear boundaries to large societies with unclear boundaries. New cultural types emerged to adapt to large societies with unclear boundaries.

With unclear boundary, the worldview was transformed from territorial worldview to competitive worldview or connective worldview. With large society, instinctive interdependent sociality among various professions was still important to prevent individuals from leaving society, but it became a background instinctive sociality without the power to control the large society as it was difficult to determine precisely interdependent relationship in a large society. The primary instinctive sociality in control was transformed from interdependent sociality to individualistic sociality or collectivistic sociality. The four new primary cultural types in the Agricultural-Nomadic Period were individualistic competitive, collectivistic competitive, individualistic connective, and collectivistic connective cultural types. Agricultural society and nomadic society developed different worldviews. In sedentary agricultural society, the main economic 
growth model was the economic gain in agricultural products from the investment in the complex infrastructures, such as market, transportation, and irrigation. The infrastructure involves both basic physical and organizational structures-facilities. Agricultural society was motivated to form alliances in order to connect the infrastructures among city-states. As a result, agricultural society developed connective worldview to view the world as connective city-states. In mobile nomadic society without a fixed settlement for the complex infrastructures, the main economic growth model was the economic gain from the plundering of properties by conquest. The plundering of properties by conquest in nomadic society generated the competitive world, so nomadic society developed competitive worldview to view the world consisting of competitive tribes.

Nomadic society by itself did not have enough people and natural resource to establish great civilization, but in the West, the nomadic society conquered the agricultural society, and established competitive worldview in the conquered agricultural society. Competitive worldview is the major worldview of the West originated from the Middle East and Greece, while connective worldview is the major worldview of the East originated from India and China. The two groups of nomads in the West were the Semitic nomads and the Eurasian nomads. In the West, the agricultural Middle Kingdom (2120 - 1780 BC) of Egypt was conquered by a Semitic nomad, Hyksos. The agricultural Sumer was conquered by Akkad related to Semitic nomad outside of Sumer. After the conquests by the nomads, both Egypt (the New Kingdom 1550 - 1069 BC) and Mesopotamia (the Akkadian Empire 2350 - 2150 BC) turned into aggressive imperialistic empires with competitive worldview. (The Middle Kingdom and Sumer were not imperialistic.) Afterward, competitive worldview has been firmly established in the West. For the East, in agricultural Indus Valley and Yellow River Valley, connective worldview of agricultural society reversed or resisted competitive worldview of the invading nomads, so the East retained connective worldview. The competitive West pursues global military hegemony by defeating competitors in the perceived competitive world, while the connective East builds the infrastructure for clothing, food, shelter, and transportation in the perceived connective world. Historically, many large empires in the West occupied more than one continent. During the period of colonization from the 1500s to the 1960s, the Western countries enriched themselves by global conquest. The West colonized partially or totally almost all countries in the world. The East has not developed permanently aggressive imperialistic empires with competitive worldview as neither China nor India has reached beyond Asia. The West has the competitive chimpanzee culture with competitive worldview, while the East has the connective bonobo culture with connective worldview.

Instinctive worldview affects perceptions. For connective worldview, the perception that focuses in connective ingroup is "relationship perception" to build relationship among members in ingroup, while for competitive worldview, the perception that focuses in competitive outgroup is "identity perception" to differentiate the identity of outgroup from the identity of ingroup. With instinctive 
connective relationship perception from connective worldview, the Easterners see a world of continuous and connected objects with relationships, while with instinctive discrete identity perception from competitive worldview, the Westerners see a world of discrete and unconnected objects in categories based on similarity and difference. The Westerners pay attention to the focal object separated from its surrounding based on discrete perception, while the Easterners attend more broadly to the overall surroundings and to the relations between the object and the field [5] [6].

\subsection{Moralities and Religions}

Instinctive worldview also affects morality. The morality of connective worldview is opposite to the morality of competitive worldview. In connective worldview morality, morality is connective described in highly favorable terms, and immorality is competitive described in highly unfavorable terms. For individualistic connective cultural type, the moral behavior is connective as reciprocity where both individuals cooperate with each other, and the immoral behavior is competitive as egotism where one individual divides oneself from other individuals. For collectivistic connective cultural type, the moral behavior is connective as cohesive relationship to keep multiple groups cohesive, and the immoral behavior is competitive as divisive bigotry to look down certain groups of people in multiple groups. In competitive worldview morality, morality is competitive described in highly favorable terms, and immorality is connective described in highly unfavorable terms. For individualistic competitive cultural type, the moral behavior is competitive as freedom to compete, and the immoral behavior is connective as restriction of the freedom to compete. For collectivistic competitive cultural type, the moral behavior is competitive as supremacy of the group over multiple groups, and the immoral behavior is connective as inferiority of the group below multiple groups. Competitive worldview considers moral reciprocity in connective worldview as immoral restriction to interfere individualistic freedom, and considers moral cohesive relationship in connective worldview as immoral inferiority to accommodate outside groups. Connective worldview considers moral freedom in competitive worldview as immoral egotism to be inconsiderate of other people, and considers moral supremacy in competitive worldview as immoral divisive bigotry.

The three most important individualistic-collectivistic competitive religions in the West are Judaism from Israel, Greek individualism from Greece, and Islam from Arab. Greek individualism includes individualistic Greek mythology and Greek philosophy. The Israel tribe was herd-nomadic tribe, Greece with the strong influence from Athenian culture was trade-nomadic society for trading olive oil, and Arab was both herd- and trade-nomadic tribe. Herd-nomadic society required strong collectivistic government to protect a tribe, so herd-nomadic society developed collectivistic competitive cultural type. Judaism unified 12 herd-nomadic clans to become collectivistic competitive cultural type. Tradenomadic society developed trading cities to trade goods from different places. In 
a trading city of trade-nomadic society, a high degree of freedom was required among individual traders from many different cultural and political backgrounds to trade and to exchange information freely, so trade-nomadic society developed individualistic competitive cultural type. Greek individualism unified trading city states to become individualistic competitive cultural type. Arab was the mixture of both herd-nomadic society and trade-nomadic society. Islam unified both herd-nomadic and trade-nomadic clans to become individualistic-collectivistic competitive cultural type.

In China, India, and the Far East for the East, the worldview is connective worldview with connective morality. The rulers in China and India were mostly agricultural people. Originated from agricultural India, Hinduism is a connective religion with the Vedas among the oldest sacred texts. Originated from agricultural China, Confucianism is a connective religion. Connective cultural type can be individualistic or collectivistic. Thomas Talhelm shows that southern China with rice agriculture that requires extensive cooperation for irrigation among farmers is collectivistic, whereas the north with wheat agriculture that has no such requirement is individualistic [24]. Hinduism and Confucianism contain both individualistic and collectivistic connective cultural types.

The complete transformation from individualistic or collectivistic local territorial religions with territorial worldview into global religions with connective or competitive worldview typically required the loss of clear boundary due to the downfall of nation. Without clear boundary, local religions with territorial worldview ceased to exist. During and after the falls of ancient Israel and Judah, the prophets transformed local Judaism into global Judaism whose God controls the whole world without boundary. During the time of Confucius, the central government in China was no longer in control, and there was no clear boundary among various local powers in China. Hinduism was evolved among local powers without a strong central power and clear boundary. Under the influence of Judaism, Islam is also a global religion.

The formations of instinctive individualistic sociality and instinctive collectivistic sociality in the Agricultural-Nomadic society generated a backlash to return to instinctive interdependent sociality practiced in the prehistoric periods, resulting in the emergence of the interdependent religions (Christianity, Buddhism, and Daoism) [3]. Bypassing the sacred civilized contract as the laws of the Old Testament, Christianity practices the interdependent ways of life in the Religious Prehistoric Period manifested as the sacred eusocial kingdom of God based on love and the interdependence among the followers of Jesus Christ. Bypassing both the sacred civilized contract as the complex Vedic laws and the sacred guardians as various deities, Buddhism practices the interdependent ways of life in the Secular Prehistoric Period manifested as the secular eusocial sanctuary based on compassion, meditation, impermanence, and interdependence. Bypassing civilized moral codes and various deities, Daoism practices the interdependent ways of life in the Secular Prehistoric Period manifested as the secular eusocial small remote state based on yin-yang interdependence, natural intui- 
tion, and the unity with the nature.

The ideal cultural type for Daoism is interdependent territorial cultural type. In Chapter 80 of Dao De Jing, the ideal countries are small countries whose residents can see neighboring countries, and can hear roosters and dogs from neighboring countries, but will age and die without visiting one another. There is a clear boundary between adjacent countries. Christianity, Buddhism, and Daoism thrive as the collections of small groups with boundaries as small-group prehistorical human society. Their natural cultural type is interdependent territorial cultural type which is the core of Christianity, Buddhism, and Daoism. Other cultural types involving large group politics and economy are not suitable for actual daily interdependent living in interdependent religions. The organization of interdependent territorial cultural type religions in urban environment without extended family at one location can be the three-tier organization consisting of large group (greater than 250 people), the middle group (about 100 250 people), and the small group (6 to 15 people). Dunbar proposed that humans can comfortably maintain only 150 (Dunbar's number) stable relationships in between 100 and 250 people [25] which is for the middle group. The small group is for intimate group where people can actually support emotionally one another. The large group is for formal group with the same religious belief. Each group in each tier has a boundary. The interdependent religions are separated from other cultural types with proper boundaries such as the separation of interdependent religion and political state.

\subsection{Modernity as Rational Local Homogeneity}

The Agricultural Revolution transformed small society into large society without clear boundary. A large society likely contained multiple authoritative traditions. In a large society, the conflicts among different authoritative traditions were inevitable, resulting in the chaotic large society with conflicting authoritative traditions. The rational cultural transformation from the chaotic to the rational large society was established by orderly rational system to replace conflicting authoritative traditions. In the East, the rational cultural transformation to reach continuous modernity occurred during the Axial Age by Buddha, Confucius, and Laozi who did not claim themselves as the representatives of authoritative gods. The original sources of Confucianism, Daoism, and Buddhism, in their original forms by their founders were based on rational systems. As a result, Confucianism, Daoism, and Buddhism are rational religions instead of authoritative religions. Under the influence of Buddha, rational Hinduism produced the Upanishads where the truth can be reached by a strictly personal effort in terms of knowledge. In the West, classical Greek philosophy by Socrates, Plato, and Aristotle during the Axial Age was also a rational system without relying on authoritative gods. A famous dictum from Socrates is "the unexamined life is not worth living". However, the modernity by classical Greek philosophy was intermittent instead of continuous until the Renaissance.

Freeing people from the restriction of authoritative tradition and bringing the 
rational order to the chaotic society, modernity expanded civilization and wealth. Since the East started continuous modernity thousands years earlier than the West, the East (India and China) was the wealthiest region for thousands years before the Industrial Revolution. In the West, classical Greek rational philosophy prevailed in the Hellenistic world and then the Greco-Roman world where civilization and wealth expanded until the domination of the three authoritative Abrahamic traditions: Jewish, Christian, and early Islamic traditions. During the Middle Ages, the Arabs adopted classical Greek philosophy to expand civilization and wealth until the return of the authoritative Islamic tradition. In the West, the rational cultural transformation to reach continuous modernity started from the European Renaissance (about 1420 - 1630) thousands years after continuous modernity in the East. The Renaissance was influenced by classical Greek philosophy from the Arab countries which actually started modernity earlier. In the West, continuous modernity produced modern science and the Industrial Revolution that greatly expanded civilization and wealth. The Industrial Period was started by the Industrial Revolution about 250 years ago. The Industrial Revolution replaced an economy based on manual labor by one dominated by machinery. The dramatic increase in productivity lifted most people from the poverty. The Industrial Revolution started in the mid-18th century and early 19th century in Britain and spread throughout the world. The Industrial Revolution has improved human living condition tremendously.

Modernity is defined as rational local homogeneity within a cultural type. In modernity, different cultural types have different rational systems for politics, economy, and foreign policy. For competitive, connective, and territorial worldviews, the modern rational systems are the rational-legal, the rational-infrastructural, and the rational-territorial systems, respectively. The rational system for competitive worldview is the rational-legal system which is the rational competitive network. Each person is a competitor whose goal of life is to win competition under the rules in the rational-legal system. The origin of legality is large competitive trading society such as ancient Greek trading society which required exact legal contracts for all trading transactions for orderly competitive trade. In individualistic competitive cultural type, the rational-legal system for politics is liberal democracy for individualistic political competition where each individual has the freedom to compete politically under the rule of law. The document for the political rational-legal society is constitution which is precise and exact. Liberal democracy consists of three components: the state, the independent rule of law, and the independent accountability as described by Francis Fukuyama [26] [27]. The independent rule of law and the independent accountability protect the right and freedom of individuals. The independent accountability is through the competition of votes among individuals in the competitive democratic procedure. For collectivistic competitive cultural type, the political rational-legal system is ideological collectivism for collectivistic group political competition where each rational-legal system has a single collectivistic ideology, such as communism, to compete against other rational-legal systems with dif- 
ferent ideologies. Ideology in ideological collectivism is the rational-legal system. The independent rule of law and the independent accountability to protect the right and freedom of individuals are weak in ideological collectivism.

The rational system for connective worldview is the rational-infrastructural system which is the rational connective network. Each person is a responsible worker whose goal of life is to fulfill each person's social responsibility under the rational-infrastructural system. The rational-infrastructural system for politics is meritocracy based on merits (achievements) which are typically measured by education, examination, ethics, experience, and job preformation. Individualistic meritocracy emphasizes individual merits, while collectivistic meritocracy emphasizes the merit of the whole group. Meritocracy is infrastructural connective politics, while liberal democracy or ideological collectivism is legal competitive politics.

In China, meritocracy originated from the Zhou dynasty in $1046 \mathrm{BC}$ with the concept of the Mandate of Heaven where the Heaven grants emperors the right to rule based on their merit to govern well, appropriately and fairly independent of noble birth. According to this belief, the emperor who does not the merit to rule as emperor loses the Mandate and thus the right to be emperor. As a result, the Zhou required all nobilities in aristocracy to be highly educated, skillful, and virtuous. Confucius (551 BC-479 BC) conceptualized the social infrastructure starting from family as the base for the political infrastructure for common people. The Qin dynasty (221 BC-206 BC) that unified China after the long period of the division in China abolished the aristocratic administration, and established the meritocratic administration from common people independent of patrimony. The Han Dynasty in the second century BC introduced the world's first civil service exams evaluating the merit of officials for the implementation of meritocracy. China has practiced meritocracy for thousands years more or less continuously since then. In India, meritocracy extended to the life during continuous reincarnation. In India, the upward mobility in reincarnation was through merit independent of patrimony in the caste system. Each caste had its own social responsibility. Such meritocracy in reincarnation kept relatively peaceful coexistence among the four classes in the caste system and among different small kingdoms.

The political breakdown of Christendom control by Christian church in Europe resulted in the Thirty Years' War (1635-1659) among various Protestant and Catholic states. The conclusion of the war was that clear national boundaries were needed to allow each nation to decide ingroup and outgroup in terms of religious preferences of the nations. The rational-territorial system with clear boundary was a rational adaptation to the breakdown of ideological collectivism as the cultural type of Christendom. The rational-territorial system disrespects legal and infrastructural systems, and respect clear boundary. The rational-territorial society defines ingroup and outgroup based on political-geographic boundary or ethnic-geographic boundary. Morality is clear boundary, while immorality is unclear boundary. The political systems are individualistic territo- 
rialism and collectivistic territorialism for individualistic territorial and collectivistic territorial cultural types, respectively. All modern nations and regional communities incorporate territorialism in various degrees depending on the importance of boundary. For nations, political individualistic territorialism is civil nationalism with geopolitical boundary. Political collectivistic territorialism is ethnic nationalism with both geopolitical boundary and ethnic boundary, and all citizens in ethnic nationalism are united under one dominant ethnic group.

Each political system has its inherent weakness that can cause dysfunctional political system. The inherent weakness in liberal democracy is inequality. The competition among individuals inevitably leads to winners and losers, resulting in inequality. Extreme inequality typically occurs during technological revolution when new technology destroys old technology. Currently, the richest $1 \%$ of the population in the USA owns $38 \%$ of all privately held wealth. The failure of preventing extreme inequality brings about dysfunctional liberal democracy controlled by wealthy oligarchy (the top one percent) regardless of the outcome of democratic election. The wealthy oligarchy controls politics by money, which does not represent the best interest of the whole society. The inherent weakness in ideological collectivism is dissent. A very large society is typically pluralistic. In competitive worldview, pluralism becomes competitive pluralism. Ideological collectivism maintains one ideology without pluralism. The result is the inevitable dissent from competitive pluralism. The failure to prevent strong dissent brings about dysfunctional ideological collectivism which is totalitarianism to severely suppress dissent by force or sectarianism to undergo continuous conflict among competitive social groups. The inherent weakness in meritocracy is corruption. Competition naturally provides checks and balances to prevent extreme corruption. Without competition, connective meritocracy does not naturally provide checks and balances to prevent extreme corruption. The failure to prevent extreme corruption leads to dysfunctional meritocracy and the loss of trust in government. The inherent weakness in territorialism is the separation between ingroup and outgroup, leading to social injustice.

The modern rational economies are private free market economy (capitalism), state command economy (statism), connection economy (communitarian capitalism), and protectionism economy derived from individualistic competitive, collectivistic competitive, connective, and territorial cultural types, respectively. The primary national goals of capitalism, statism, connection economy, and protectionism economy are economic growth, equality, employment, and security, respectively. In the world today, capitalism and statism dominate. Meanwhile, the industrial East also develops connective economy based on connective worldview as practiced in Japanese economy including zaibatsu (collectivistic group connection economy) and keiretsu (individualistic reciprocal connection economy) for individualistic connective and collectivistic connective cultural types, respectively. Protectionism economy based on territorial worldview protects ingroup from outgroup. Individualistic protectionism is market protectionism, while collectivistic protectionism is command protectionism. 
Each economic system has its inherent strength and weakness. Major technological breakthroughs are typically initiated by private free market economy because of its diversity, flexibility, and innovation by highly motivated individuals. With competition, unproductivity is eliminated resulting in productive economy. However, because the private capitals of individuals are limited, it is fragmented and fragile, resulting in occasional economic collapses by over-demand or over-supply. State command economy based on ideological collectivism provides the collective passion to undergo innovative development of specific economic segments, such as heavy industry and defense-space industry to benefit ideological collectivism, but total economic development is burdened by ideology, resulting in fragmented and fragile economy. Without competition, connection economy is not innovative enough to initiate major technological breakthroughs, and is typically unproductive, but it can imitate and catch up fast because of the collaborative strength of private or state connection economy. It is also durable enough to avoid major economic collapse even under severe economic slowdown. Connection economy also is more pragmatic and less centralized than state command economy, so connection economy is more diverse and initiative than state command economy. Protectionism economy provides simplicity and security, but without external economic input, the economic progress is greatly retarded.

The three foreign policies are offensive foreign policy from competitive worldview, infrastructural foreign policy from connective worldview, and territorial foreign policy from territorial worldview. An important theory for Western foreign policy is John Mearsheimer's offensive foreign policy from offensive realism [28] which posits that the international system is perceived realistically as the competitive anarchic international system. In the competitive anarchic international system, all states possess some offensive military capability, and states can never be certain of the intentions of other states. States have survival as their primary goal. States are rational actors who are capable of coming up with sound strategies that maximize their prospects for survival by military offense capable of defeating other states. The result of offensive realism is offensive foreign policy involving inevitably and tragically wars and conflicts as described in John Mearsheimer's “The Tragedy of Great Power Politics” [28].

The second realism is infrastructural realism which perceives realistically the international system as the disconnected anarchic international system. In the disconnected anarchic international system, all states with some goods and service capability require international trade to survive and prosper, and states can never be certain of the intentions of other states. States have survival and prosperity as their primary goals. States are rational actors, capable of coming up with sound connective infrastructure for international trade that maximize their prospects for survival and prosperity, resulting in infrastructural realism for infrastructural foreign policy. The main foreign policy is economical instead of military, so the main military strategy is low-profile defense instead of highprofile offense as in offensive foreign policy. Throughout history, infrastructure 
has been central to national and international cohesion and economic growth, connecting countries to themselves and to one another. In China, historically, trades and intermarriages among agricultural group and surrounding nomad groups were common and encouraged most of times, resulting in the famous Silk Road. The recent One Belt, One Road (OBOR) is a current version of infrastructural foreign policy.

The third realism is territorial national-regional realism which perceives realistically the international system as the unclear boundary anarchic international system. In the unclear boundary anarchic international system, all states possess some national-regional boundaries, and states can never be certain of the intentions of other states. States have survival as their primary goal. States are rational actors, capable of coming up with clear national-regional boundaries that maximize their prospects for survival, resulting in territorial realism for territorial foreign policy. All nations enforce national territorial foreign policy. Some regions enforce regional territorial foreign policy, such as the Western Hemisphere's "Monroe Doctrine" that forbids military intervention from the countries outside of the Western Hemisphere. The perceptions, moralities, religions, politics, economies, foreign policies, and great apes of the seven primary cultural types are listed in Table 1.

Each cultural type has its inherent strength and weakness in modern politics and economy, so each cultural type has to be modified by other cultural types to minimize its weakness. Almost all countries practice some forms of mixed politics and economy. Confucian meritocracy began its popularity in Europe in the

Table 1. Cultural Types.

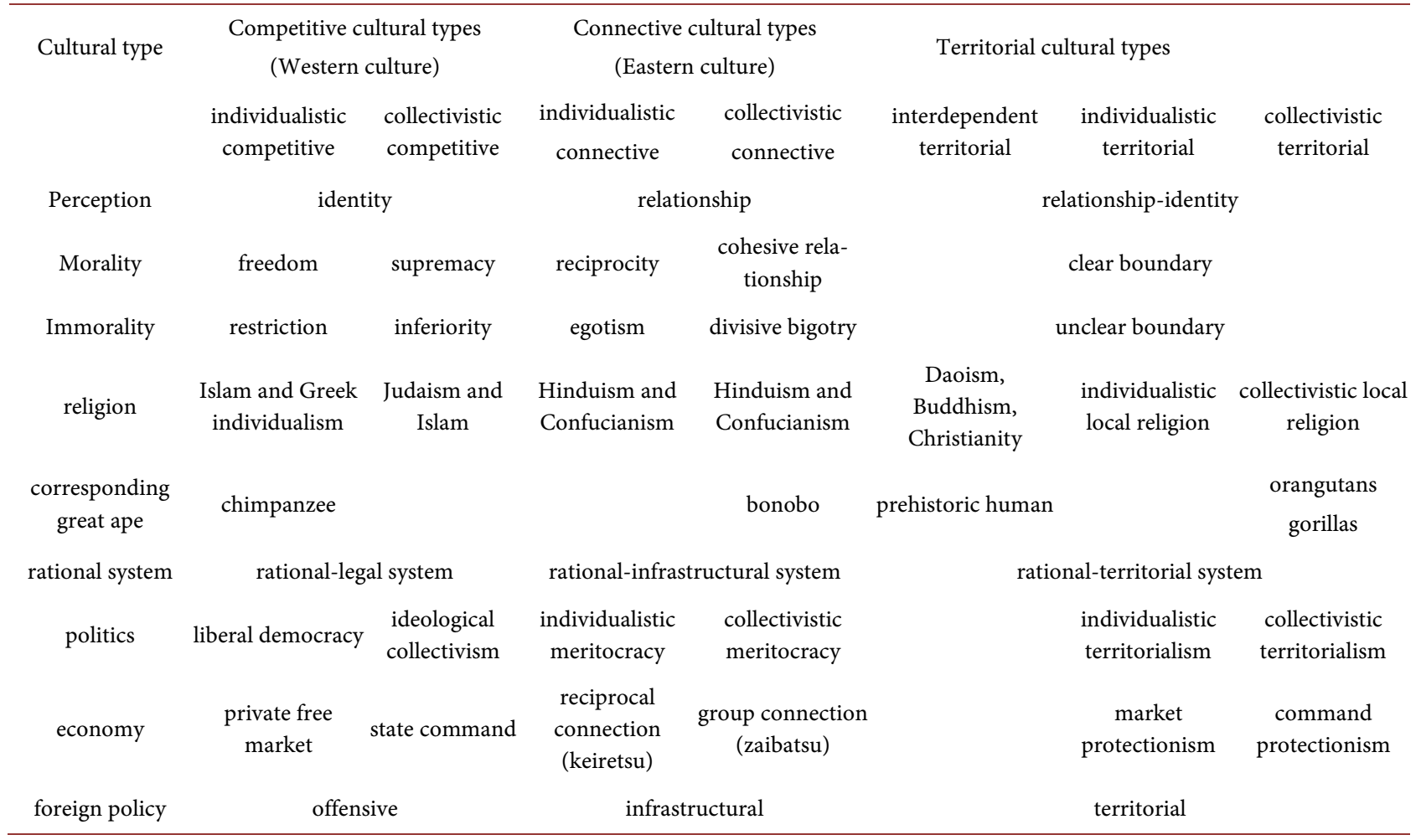


$19^{\text {th }}$ century, so to improve the quality of civil service, Europe and America introduced merit-based civil services. Since then, the European and American political systems have been liberal merito-democracy. Different countries have different degrees of meritocracy. The inherit weakness of liberal democracy is inequality. Europe and America incorporated ideological collectivism under the ideological programs to promote social and economic equality in the $20^{\text {th }}$ century. In this way, inequality is minimized. Most governments with ideological collectivism practice the mixed political system by adopting some parts of liberal democracy.

Meritocracy practiced in China is also a mixed political system described by Daniel A. Bell [29] as the combination of ideological collectivism (socialism), liberal democracy, and meritocracy. The mixed system can be generalized and idealized as the professional four branch ideological democratic meritocracy consisting of the executive, the legislative, the judicial, and the governmental service branches. The governmental service branch is the combination of human resource (HR) and public relation (PR) of professional government. For human resource, the governmental service branch establishes training programs to train potential and current government employees, provide qualification examinations, certify all government employees by grades based on meritocratic qualifications, and to hold local democratic election. For human resource, the ethics department establishes ethics rules and standards of conduct as well as investigation and prosecution of corruption. For public relation, the governmental service branch explains the structure and the mission of government, and promotes and explains the government policies to all citizens, and it also conducts the opinion polls about the performances of governments and policies. All top government positions have term limits.

In the professional four branch democratic meritocracy, different size governments fit different political systems, so the professional four-branch democratic meritocracy has the three-tier system consisting of small size, medium size, and large size government for different political systems. The basic concept of the three-tier system is democracy on the bottom, experimentation in the middle, and meritocracy on top [29]. Small size government is local government for local politics which allows democracy. All candidates have to be qualified through merit by the governmental service branch. In local politics, living together in the same area provides commonality, and dealing with daily life provides pragmatism. Commonality and pragmatism allow local politics to practice democracy consisting of local state, independent local judicial court, and independent local accountability through local competitive voting. Prosperous middle class demands self-expression politically at the local level for daily life. The local democracy gives people a sense of belonging in the political system. As shown in the USA, partisan politics does not play an important role in local democratic procedure which deals with very practical issues related to daily life without involving ideology.

Outside of local politics, politics has less commonality and practicality. Large 
area politics has to deal with national or regional identity, religious identity, social morality, and the distribution of wealth among locations and groups. In contrast to commonality and pragmatism in local politics, pluralism and impracticality appear in large area politics. It is very difficult to practice liberal democracy without commonality and practical standard, and to achieve what all people consider as a good government. Outside of local politics, the politics is meritocracy. Qualified elected local officials and other local officials are selected and promoted to the different positions in regional and national government by meritocracy. (In some cases, a medium size government can be elected by democracy if there is enough commonality.) By meritocracy that selects national officers from local officers, the national government represents different local groups in the pluralistic society, and the top national officials are highly experienced and accomplished.

Ideological collectivism such as socialism is incorporated to promote social and economic equality which is important for national unity, so the mixed political system becomes ideological democratic meritocracy such as socialist democratic meritocracy. In China, Confucius established meritocracy to last for thousands years, Sun Yat-sen started liberal democracy to replace the imperial Qing dynasty, Mao Zedong instituted ideological collectivism to unify China, and Deng Xiaoping founded socialist democratic meritocracy as the proper political system through seeking truth from the facts. The facts were that competitive liberal democracy by Sun Yat-sen and competitive ideological collectivism by Mao Zedong did not work well for the development of China which has connective worldview. With connective worldview as the primary worldview and competitive worldview as the secondary worldview, socialist democratic meritocracy by Deng Xiaoping establishes meritocracy for connective political infrastructure, institutes democracy for political participation without partisan competition, and supports socialism for equality without class competition. The political system in China is the professional three-branch-one-party socialist democratic meritocracy which can evolve into the professional four branch socialist democratic meritocracy.

All advanced countries practice the mixed economic systems consisting of private free market economy, state command economy, and connection economy. The mixed economy of private free market economy and state command economy involves state interventionism and state owned enterprise to counter volatility, fragmentation, and inequality in private free market economy. Connection economy allows the formation of strategic partners as reciprocal partners or group partners to counter fragmentation in private free market economy. Private enterprises provide diversity and complexity to produce most goods and service, economic growth, and employment. Large enterprises can be private or state enterprises. Large state enterprises based on state command economy provide enterprise incubators to start new technological fields and and strategic enterprises to maintain critical national interests. Different advanced countries have different distributions of private free market economy, state command 
economy, and connection economy during different stages of economic development.

\subsection{Postmodernity as Rational Global Diversity}

In about 1970's, individualistic competitive cultural type started the Information Revolution involving extensively computers and wired and wireless networks to store, manipulate, and transmit information. The three major irreversible consequences of the Information Revolution are global interdependence, extensive automation, and ubiquitous global information network. Global communication through information technology allows global interdependence in terms of global division of labor. Different countries specialize in producing different goods, services, and raw materials. Today, very few products are manufactured entirely in a single country, and people consume products daily from all over the world. Through information technology, extensive automation to replace human workers increases productivity and product quality, and reduces overall costs. (Automation instead of globalization is the major force for the loss of employment.) The usage of ubiquitous global information network in terms of e-commerce, instant news, and social media becomes necessary part of daily life for people in developed countries and many developing countries.

The start of the Information Revolution by individual competitive cultural type and the end of the Cold War in early 1990's resulted in the domination of individualistic competitive cultural type in terms of democracy-capitalism-freetrade. All countries had to use individualistic competitive cultural type as the global standard to adjust and justify their cultures accordingly as described in "The End of History" [30] by Fukuyama who claimed that the human history was ended with liberal democracy and private free market economy. Individualistic cultural type suppressed other cultural types. However, liberal democracy has not dominated the world. According to the Democracy Index by the Economist Intelligence Unit (the world's leading resource for economic and business research) [31], in 2015, only 20 countries (8.9\% of the world population) are "full democracies", 59 (39.5\%) are "flawed democracies", 37 (17.5\%) are "hybrid regimes (illiberal democracy)", and 51 (34.1\%) are "authoritarian regimes".

Various factors have contributed to the failure of the domination of individualistic competitive cultural type. One of the factors is the chaos caused by international terrorism. The USSR could not afford the continuation of the nationbuilding in Afghanistan, resulting in the power vacuum for the emergence of the initial international terrorism. America also could not afford the continuation of the nation-building in the Middle East, resulting in the power vacuum for the emergence of the new international terrorism. The Great Financial Crisis of 2008 discredited capitalism. The Arab Spring for democracy in 2011 produced mostly chaos instead of the expected democratic breakthrough. At the same time, globalization and automation have resulted in insecurity and inequality in some democratic countries which have moved toward nationalism-protectionism. The consequence of international terrorism, the Great Financial Crisis of 2008, the 
failure of the Arab Spring, and nationalism-protectionism is the loss of the domination of individualistic competitive cultural type in terms of democracy-capitalism-free-trade. Without an absolutely domineering cultural type, the cultural types in the diverse global society clash, resulting in today's chaotic diverse global society.

\subsubsection{The Three-Tier International Politics}

This paper proposes that today's chaotic diverse global society can be transformed into the orderly rational diverse global society by the rational global diverse systems, bringing about the coming postmodernity with multiple cultural types. The proposed rational global diverse systems for the coming postmodernity consist of the nine cultural types derived from the instinctive cultural type model. Different countries can be cataloged by the cultural types. According to the Democracy Index, most "full democracies" for individualistic competitive cultural type are in the Western Europe and the Northern America. At the same time, ideological collectivism with religious value as ideology for collectivistic competitive cultural type is located in the Middle East. In the East, individualistic-collectivistic connective cultural types in terms of meritocracy-connection economy have made the rapid economic development. Most other developing countries in South America and Africa are not globalized enough, so they are individualistic-collectivistic territorial cultural types. Therefore, the four cultural type blocks with six cultural types for politics and economy are individualistic competitive, collectivistic competitive, individualistic-collectivistic connective, and individualistic-collectivistic territorial cultural type blocks. The other three cultural types which do not involve and control directly politics and economy are interdependent territorial cultural type for interdependent religions (Christianity, Daoism, and Buddhism) and interdependent competitive-connective cultural types as the background cultural types to prevent individuals from leaving human society.

The establishment of the religious-geographic boundaries ended the religious war in the Thirty Years' War among Protestant and Catholic states. In the same way, the establishment of the cultural-geographic boundaries will end the cultural clash among cultural types. As a result, the rational global diverse system for the postmodern international politics is the three-tier international politics consisting of nations with geopolitical boundaries, the 12 regional communities with cultural-geographic boundaries, and the global international organizations without boundary. The regional communities exist in the "World Regional Community Organization" (the WRCO) where every country in the world belongs to a regional community. The countries in one geographic region can find common identities to establish one regional community. The common identities of a regional community include some or all of the shared geography region, shared cultural type, shard dominant language, shared dominant religion, and shared existing regional international organization. Each regional community has at least one economically strong country for its protection and strength. In 
this way, different regional communities become the different strongholds for different regions, cultural types, languages, religions, and existing regional international organizations. The 12 communities in the World Regional Community Organization (WRCO) are as follows.

The North American Community (individualistic competitive, English-Spanish-French, Christianity, under NAFTA)

Canada, Mexico, the USA

The South American Community (territorial, mostly Spanish-Portuguese, Christianity, OAS)

Antigua and Barbuda, Argentina, Bahamas, Barbados, Belize, Bolivia, Brazil, Chile, Colombia, Costa Rica, Cuba, Dominica, Dominican Republic, Ecuador, El Salvador, Grenada, Guatemala, Guyana, Haiti, Honduras, Jamaica, Nicaragua, Panama, Paraguay, Peru, St. Kitts and Nevis, St. Lucia, St. Vincent and The Grenadines, Suriname, Trinidad and Tobago, Uruguay, Venezuela

The East Asian Community (connective, mixed languages, mostly under Confucian influence)

China, Japan, Mongolia, Philippines, the Republic of Korea, the Democratic People's Republic of Korea, Viet Nam

The South Asian Community (connective, mixed languages, under Indian influence)

Bangladesh, Bhutan, Brunei, Cambodia, Laos, Malaysia, Singapore, India, Indonesia, Maldives, Myanmar, Nepal, Sri Lanka, Thailand, Timor-Leste

The Midwest Asian Community (collectivistic competitive, mixed languages, Islam)

Afghanistan, Iran, Iraq, Pakistan, Turkey

The Southwest Asian Community (collectivistic competitive, mostly Arabic, mostly Islam, mostly Arab League)

Bahrain, Israel, Jordan, Lebanon, Kuwait, Oman, Palestine, Qatar, Saudi Arabia, Syria, the United Arab Emirates, Qatar, Yemen

The Eurasian Community (connective, mixed languages, Christianity-Islam, former USSR)

Armenia, Azerbaijan, Belarus, Georgia, Kazakhstan, Kyrgyzstan, Russia, Tajikistan, Turkmenistan, Uzbekistan

The West European Community (individualistic competitive, mixed languages, mostly Christianity, mostly EU)

Albania, Andorra. Austria. Belgium. Bosnia and Herzegovina, Bulgaria. Croatia. Cyprus. Czech Republic, Denmark, Estonia, Finland, France, Germany, Greece, Hungary, Iceland, Ireland, Italy, Kosovo, Latvia, Liechtenstein, Lithuania, Luxembourg, Macedonia, Malta, Moldova, Monaco, Montenegro, Netherlands, Norway, Poland, Portugal, Romania, San Marino, Serbia, Slovakia, Slovenia, Spain, Sweden, Switzerland, Ukraine, the United Kingdom, Vatican City

The North African Community (territorial, mostly Arabic, Islam, CEN-SAD and Arab League)

Algeria, Comoros, Burkina Faso, Djibouti, Egypt, Gambia, Guinea, Gui- 
nea-Bissau, Libya, Mali, Mauritania, Morocco, Niger, Senegal, Sierra Leone, Somalia, Sudan, Tunisia, Western Sahara

The West African Community (territorial, mixed languages, mostly Christianity, ECOWAS and ECCAS)

Benin, Cape Verde, Cameroon, Central African Republic, Chad, Côte d'Ivoire, Democratic Republic of the Congo, Equatorial Guinea, Gabon, Ghana, Liberia, Nigeria, Republic of the Congo, São Tomé and Príncipe, Togo

The East-South African Community (territorial, mixed languages, mostly Christianity, COMESA, EAC, and SADC)

Angola, Botswana, Burundi, Eritrea, Ethiopia, Kenya, Lesotho. Madagascar, Malawi. Mauritius, Mozambique, Namibia, Rwanda, Seychelles, South Africa, South Sudan, Swaziland, Tanzania, Uganda, Zambia, Zimbabwe

$\underline{\text { Pacific Islands Forum Community (individualistic competitive, English, }}$ Christianity, Pacific Islands Forum)

Australia, Fiji, Kiribati, Marshall Islands, Micronesia, Nauru, New Zealand, Palau, Papua New Guinea, Samoa, Solomon Islands, Tonga, Tuvalu, Vanuatu

Each cultural type block has its own politics and economy. The individualistic competitive cultural type block includes the North American, the West European, and the Pacific Island Forum Communities. The countries have Christian tradition. The North American Community is under the NAFTA (North American Free Trade Agreement). The West European Community is mostly under the EU (European Union). The Pacific Island Forum Community is under the Pacific Island Forum. The individualistic competitive cultural type block practices liberal merito-democracy, private free market economy, and international free trade. International free trade is important. For example, almost half of all revenue for top American companies in the S \& P 500 comes from outside the United States, mainly Europe and Asia. The conversion to protectionism and the trade war with major trade partners will be devastating to such globalized economy. The economic specialty of free market economy is its innovation and global marketing which generate high-tech products with high profit. The political strength of liberal merito-democracy is its rational-legal system and tradition to provide orderly political competition. Individualistic competitive cultural type block has remained the wealthiest and strongest cultural type block. The primary cultural type is individualistic competitive cultural type, but the most adaptable system requires some modifications by other cultural types. According the Democracy Index, the top democratic countries are from the Northern Europe whose political system is modified by the Judeo-Christian value of justice, equality, and human dignity to counter inequality. Full democracy requires the minimization of inequality. The primary foreign policy is offensive policy which has to be modified by infrastructural policy and territorial policy for the world peace.

The collectivistic competitive cultural type block includes the Midwest Asian and the Southwest Asian Communities. The political system is ideological collectivism. The Southwest Asian Community is mostly Muslim, and under mostly 
the Arab League. The ideology is religious value. Religious value is religious ethical principle to guide daily and political decision making. The religious value in this block is Muslim, Jewish, or Christian value. To counter the perceived morally corrupt secular world, the religious value provides coherence and stability. Different religions have different religious values. A religious tradition can be interpreted differently, so different countries with the same authoritative religious tradition have different religious values to deal with different situations. As a result, ideological collectivism in some countries is modified significantly with liberal democracy, but none of them is full democracy according to the Democracy Index. With the fast expansion of university education system for the youth and the increasingly diverse economy in these communities, democracy and free market economy become increasingly important [32], resulting eventually in ideological merito-democracy instead of liberal merito-democracy in the individualistic competitive cultural type block.

The connective cultural type block includes the Eurasian, the East Asian, and the South Asian Communities. The Eurasian Community is under the former USSR. Located in between the East and the West, the Eurasian Community combines both Eastern culture and Western culture. In terms of politics, liberal democracy and ideological collectivism with Western competitive worldview have not worked well as shown in the collapses of liberal democracy and ideological collectivism in the Eurasian Community. Now the Eurasian Community essentially practices the three-branch-one-party democratic meritocracy. Multiple religions coexist peacefully with connective worldview. In the Eurasian Community, connective Eastern culture works better than competitive Western culture in politics, economy, and religion. The countries in the East Asian Community under mostly Confucian influence and the South Asian Community under mostly Indian influence adopt modern Western science and technology which were adopted effectively first by Japan. However, Japan practices mainly connection economy (communitarian capitalism) and meritocracy based on Eastern culture. In economy, Japan with connective economy is the most Confucian country in the world. Politically, the meritocratic bureaucracy dominates Japanese democratic politics with one dominating political party. China has the professional three-branch-one-party socialist democratic meritocracy. The Singapore's political system is democratic meritocracy. The competitive democratic countries in these communities have "flawed democracy" according to the Democracy Index. In many competitive democratic countries, the democratic partisan competitions are highly polarized, chaotic, and destructive. Liberal democracy is a misalignment to connective cultural type. The political system that aligns with connective cultural type is democratic meritocracy as described in Section 3.2. The conversion to democratic meritocracy is fairly easy with such top meritocratic education system and meritocratic bureaucracy. Connection economy is strong in collaboration instead of innovation. Consequently, the economic specialty is low-profit products and low-profit contract manufacturing and service. The modification of connective cultural type with other cultural 
types is necessary to optimize politics and economy.

The individualistic-collectivistic territorial cultural type block includes the South American, the North African, the West African, and the East-South African Communities. The South American Community is Christian, and under the OAS (Organization of American States). According to the Democracy Index, most countries in the South American Community have flaw democracies, only Uruguay is full democracy, and only Cuba is authoritarian. Under Western culture tradition and increasing globalization, the South America Community will most likely move toward individualistic competitive cultural type for liberal merito-democracy. The North African Community is Muslim, and under the CENSAD (Community of Sahel-Saharan States) and the Arab League. The West African Community is mostly Christian, and under the ECOWAS (Economic Community of West African States) and the ECCAS (Economic Community of Central African States). The East-South African Community is mostly Christian, and under the COMESA (Common Market for Eastern and Southern Africa), the EAC (East African Community), and the SADC (Southern African Development Community). According to the Democracy Index, the population percentages in Africa for flawed democracies, hybrid regimes, and authoritarian are $12 \%, 42 \%$, and $46 \%$, respectively. (There is no full democracy.) In African, networks of interpersonal reciprocal relations are very important. In most democratic elections in Africa, a political party does not have a clear political platform in terms of political programs. A political party basically represents an ethnic or personal group. As a result, democracy in Africa reflects mostly ethnic and personal loyalties rather than a true exercise in choosing a best political platform to govern. The democratic countries and the ideological (religious) collectivism countries that provide significant development and military aids to Africa encourage democracy or ideological collectivism in Africa. However, under increasing globalization, the more suitable political system in Africa is democratic meritocracy to move away from autocracy and chaos and to provide the social and economic needs of the people. Tanzania and Uganda practiced democratic meritocracy with good results.

The foreign policy among the regional communities can be offensive, infrastructural, or territorial foreign policy. Offensive foreign policy among the major powers leads to the Cold War confrontation with the threat of mutual annihilation from mutual nuclear offense. Today, the Cold War confrontation continues even after seemingly the end of the Cold War in early 1990's. However, the Cold War to champion certain political systems is no longer valid in today's world where no political system is definitely the champion. It is also very expensive to maintain offensive foreign policy in terms of military expenditure. Mutually destructive offensive foreign policy in the today's highly interdependent world does not make sense. Therefore, offensive foreign policy is not a viable foreign policy among the regional communities. Infrastructural international foreign policy wants to economize the world leading to mutual benefit, but it does not deal with the security of the regional communities. 
The proper foreign policy among the regional communities is territorial foreign policy with the clear defense boundaries among the regional communities. It is a defensive protective foreign policy. Each regional community is in charge of its own defense. Each regional community enforces the "Monroe Doctrine" that forbids military intrusion from the countries outside of a regional community except the intervention approved by the United Nations. As a result, all overseas military bases as the military intrusion from the countries outside of a regional community have to be abolished. Overseas military bases are essentially the remnants of the old Cold War which is now really unnecessary in the highly interdependent world. All defense treaties connected to the countries outside of a regional community also have to be ended. All intercontinental ballistic missiles have to be eliminated. The numbers of aircraft carriers have to be strictly limited to few aircraft carriers according to the area of adjacent oceans. Horrible inhuman nuclear weapons have to be abolished. Stealth aircrafts that are basically for stealth air offence should also be eliminated. Therefore, only weapons allowed are short-distant, non-nuclear, and non-stealth defensive weapons. Without expensive overseas military bases, a large number of expensive aircraft carriers, expensive stealth aircrafts, intercontinental ballistic missiles, and nuclear weapons, the military spending can be easily cut to obtain a huge peace dividend and to convert military capacity into civilian use such as natural disaster defense and relief, clean nuclear energy technology, information technology, automation technology, aeronautics and space programs, and infrastructure to benefit all people. In 2015, the world average in military spending was $2.3 \%$ of GDP. In the WRCO, the military spending for each country is set to reduce to maximum $2 \%$ of GDP and then for further reduction in the same way as the gradual reduction of tariff by the WTO (World Trade Organization).

It is the self-interest of a regional community to maintain peace in its community. Some conflicts can be defused by the creation of the special union of states where one union is composed of multiple relatively independent states with relatively open border and free trade similar to the EU. The special union of states is established to recognize and accept the two realisms: the realism of the inseparable cultural and economic connections and the realism of the significant differences among the conflicting states. The political arrangement for the special union of states can be worked out by the conflicting states under the mediation and protection from their regional communities. The Southwest Asian Community recognizes and protects the Israel-Palestine Union of the states (majority Jews and Arabs). According to the proposal by Robin Wright to remap Libya, Iraq-Syria, and Yemen [33], the North African Community recognizes and protects the Libya Union (historical Tripolitania, Cyrenaica, and Fezzan), and the Southwest Asian and the Midwest Asian Communities recognize and protect the Iraq-Syria Union of the states (majority Arab Sunnis, Shias, Alawites, and Kurds) and the Yemen Union of the states (majority Sunnis and Shias). The West European and Eurasian Communities recognize and protect the Ukraine Union of the states (majority Ukrainian speaking and Russian speaking). The 
East Asian Community recognizes and protects the Korea Union of the states (the Republic of Korea and the Democratic People's Republic of Korea). A similar solution can be established for Taiwan under the one-China policy. The East Asian Community recognizes and protects Taiwan to be the special province which is autonomous in economy, defensive force, politics, and non-political foreign relations under the Taiwan Province of China. These arrangements of the special union of states will be under the peace-unity treaties with the protection of the related regional communities. Some disputed minor territories can become special territories under some agreements to defuse minor conflicts.

The regional communities allow individual nations to maintain all international economic treaties inside and outside of the communities. Different regional communities will have different degrees of economic cooperation within the communities. It is self-interest of a regional community to invest in economically weak countries for the unity and the long-term health of the community. In postmodernity, the three-tier international politics with the enforcement of proper boundaries and the special unions of states to defuse conflicts will provide peace and rational order in the world.

\subsubsection{The Trichotomic International Trade}

This paper proposes that the rational global diverse system for the postmodern international trade contains free competitive, free connective, and fair protectionist international trades derived from competitive, connective, and territorial worldview, respectively. Free competitive international trade benefits trading countries where each country develops its own "trade specialty" with comparative advantage in international trade. Free competitive international trade provides economic growth as shown in higher economic growth for the countries with free trade than the countries with protectionism. The benefit and financial transaction from trade specialty are short-term. This short-term benefit from trade specialty often leads to long-term risk and harm due to volatility, obsolescence, over-production, over-use of specific natural and human resource, overimpact to specific environment, employment disruption, and income inequality. Free competitive international trade is necessary to provide economic growth, but diversity is needed to minimize the long-term risk and harm involving trade specialty.

The international trades based on connective and territorial worldviews provide such diversity. Free connective international trade derived from connective worldview benefits trading countries where connective infrastructure is the primary trade. Infrastructure is the backbone of connectivity which is lifeblood of commerce today. The benefit and the financial transaction are long-term. The long-term benefit involves diversity in terms of infrastructure itself and other economic activities resulted from infrastructure. Protectionism derived from territorial worldview includes protectionism to protect trade specialty and protectionism to protect trade non-specialty outside of trade specialty. Hindering economic growth, protectionism to protect trade non-specialty is allowed only if 
it is sustainable and necessary for diversity, and protectionism to protect trade specialty is allowed only if it is limited. A rational bargaining in international trade is to balance short-term economic growth from trade specialty and longterm benefit from diversity. The result is the fair protectionist international trade, including limited patent-license protection, limited wage suppression, controlled impact to environment, and limited tariff. The trichotomic international trade contains free competitive, free connective, and fair protectionist international trades, which are regulated and supported by international free trade treaties, international infrastructure investment banks, and the World Trade Organization, respectively.

International trades must respect cultural differences, and cannot be used to impose political and economic systems. The labor-intensive or semi-automated manufacture of large-scale low value products, such as clothes, shoes, and electronics, in developing countries is beneficial to developing countries for the income, and to developed countries for the low cost. The labor-intensive or semi-automated manufacture of large-scale low value products in developed countries is not sustainable in free competitive market, and is harmful to the economy in the service sector. The developed countries with low-cost energy, low-cost transportation, highly automated manufacture, and proximate market have the advantage in the manufacture of large-scale high value products, such machineries, automobiles, trains, and airplanes. Small developed countries specialize in the manufacture of small-scale high value products for specialized markets. The manufacture of high value products, the advance in competitive global innovation, and the expertise in competitive global marketing constitute the backbone of highly developed countries in economy. Culturally, connective cultural type has the advantage in manufacture, while individualistic competitive cultural type has the advantage in competitive innovation and competitive marketing. Eventually, most essential products will be commoditized available widely to be bought and made. As a result, in postmodernity, the trichotomic international trade will provide orderly international trade for different countries in different levels of development, different cultural types, and different country sizes, to bring wealth to all people, and to eventually narrow the living standard gap among all countries.

\subsubsection{The Cultural Theology of Trinity}

The original source of authoritative religions is authoritative tradition. However, theology as reasoning or discussion concerning the Deity of authoritative religion can be rational. In general, theology is the rational system to explain the generalization of authoritative tradition in religion. In other words, theology is the rational system superimposed over the authoritative tradition in religion. As a result, it is possible to establish the rational global diverse system to provide the postmodern common ground between religion as sacred authoritative tradition and science as secular rational system. The proposed system is the cultural theology of trinity consisting of the unknowable transcendental cultural origin, 
the knowable immanent cultural origin, and the imaginary cultural origin, corresponding roughly to the Father, the Son, and the Holy Spirit, respectively, in Christian theology of trinity.

The transcendental cultural origin is unknowable transcending nature. In the sacred, such cultural origin is the unseen sacred supernatural as described in the Bible, "No one has ever seen God. (John 1:8)". Even science will reach the realm which is unknowable. In the secular, such cultural origin is simply the nameless as described in the first chapter of Dao De Jing: "the name that can be named is not the eternal name; the nameless is the origin of Heaven and Earth". The sacred immanent cultural origin is the knowable sacred guardian-text. The sacred guardian emerged when vulnerable humans sought the help from the supernatural as the sacred guardian during the Religious Prehistoric Period. Different authoritative religions with different cultural types have different authoritative sacred guardians and texts. To science, the secular immanent cultural origin is scientism as the authoritative rational system where rationality itself is not questioned, and all knowable must be authoritatively, absolutely, and unquestionably rational. The imaginary cultural origin is essentially derived from the human imagination that provides the concept of the supernatural. The concept of the supernatural as religion is derived from the abstraction of imaginary objects as proposed by Maurice Bloch [23]. Both the sacred guardian-text and secular science are derived from the human imagination beyond ordinary human perception, so the sacred and the secular should not exclude one another. As long as there are vulnerable individuals to seek the sacred guardian, there is sacred religion consisting of the sacred guardian-text and the sacred community to help vulnerable individuals [34]. Individual vulnerability is omnipresent. The sacred guardian and religious social group are there to overcome individual vulnerability. Jesus said, "Come to me, all you who are weary and burdened, and I will give you rest." (Matthew 11:28) Albert Einstein said, "Science without religion is lame, religion without science is blind." In postmodernity, the cultural theology of trinity will provide the common ground for sacred authoritative tradition and secular rational system as in Table 2.

\section{Conclusion}

Premodernity, modernity, and postmodernity are defined as authoritative local homogeneity, rational local homogeneity, and rational global diversity, respec-

Table 2. The cultural theology of trinity.

\begin{tabular}{|c|c|c|c|}
\hline the Cultural & the Transcendental & the Immanent & the Imaginary \\
\hline Origins & Cultural Origin & Cultural Origin & Cultural Origin \\
\hline description & $\begin{array}{c}\text { unknowable beyond } \\
\text { nature }\end{array}$ & knowable & $\begin{array}{l}\text { imagination beyond } \\
\text { perception }\end{array}$ \\
\hline Christian terms & the Father & the Son & the Holy Spirit \\
\hline sacred terms & the sacred supernatural & $\begin{array}{l}\text { the sacred guardian- } \\
\text { text }\end{array}$ & the sacred spirit \\
\hline secular terms & the nameless & scientism & the human imagination \\
\hline
\end{tabular}


tively. Human culture has evolved from authoritative local premodernity through rational local modernity to the coming rational global postmodernity with diverse cultural types. The Agricultural Revolution transformed premodern small society into chaotic large society with conflicting authoritative traditions. The chaotic large society was transformed into the orderly rational large society by rational system, resulting in modernity with one cultural type. Different cultural types have different rational systems. The Industrial and Information Revolutions transformed modern local society into today's chaotic diverse global society with conflicting cultural types. This paper proposes that today's chaotic diverse global society can be transformed into the orderly rational diverse global society by the rational global diverse systems, bringing about the coming global postmodernity with diverse cultural types.

The proposed rational global diverse systems for the coming postmodernity consist of the nine cultural types from the instinctive cultural type model based on the instinctive sociality trichotomy (individualistic, collectivistic, and interdependent) and the instinctive worldview trichotomy (territorial, connective, and competitive). The instinctive cultural type model is the group social behavior model for advanced social animals. Different cultural types from the nine cultural types have different perceptions, moralities, religions, politics, and economies. Western culture originated from the Middle East and Greece has competitive worldview, while Eastern culture originated from India and China has connective worldview. The West has the competitive chimpanzee culture with competitive worldview, while the East has the connective bonobo culture with connective worldview. In Western culture, individualistic competitive cultural type includes liberal democracy, private free market economy (capitalism), the Greek individualism, and Islam, while collectivistic competitive cultural type includes ideological collectivism, state command economy (statism), Judaism, and Islam. In Eastern culture, individualistic-collectivistic connective cultural type includes meritocracy, connection economy (communitarian capitalism), Hinduism, and Confucianism. The interdependent territorial cultural type includes the prehistoric human society, Christianity, Buddhism, and Daoism. The individualistic-collectivistic territorial cultural types include civil nationalism, ethnic nationalism, market protectionism, command protectionism, individualistic local religion, and collectivistic local religion.

Various cultural types from the instinctive cultural type model are arranged in the rational global diverse systems for the postmodern international politics, international trade, and religion-science. The rational global diverse system for the coming postmodern international politics is the three-tier international politics consisting of nations with geopolitical boundaries, the 12 regional communities with cultural-geographic boundaries, and the global international organizations without boundary. The rational global diverse system for the coming postmodern international trade is the trichotomic international trade containing free competitive, free connective, and fair protectionist international trades. The rational global diverse system for the coming postmodern common ground be- 
tween religion and science is the cultural theology of trinity consisting of the transcendental, immanent, and imaginary cultural origins.

The coming postmodernity as rational global diversity will bring rational order and peace among global diverse cultural types. Through rational order and peace among cultural types, international terrorism that needs support from people will subside. As modernity expanded human civilization and wealth, the coming postmodernity will also expand human civilization and wealth. It will be then possible to develop the next technological revolution as the combination of conservation, automation, information technology, clean nuclear energy, renewable energy, and biotechnology. The new technological revolution will enhance wealth for all nations, and minimize the undesirable impact of human civilization on earth. Postmodernity with rational global diversity will be followed by bio-modernity with rational biodiversity. With bio-modernity, Earth will be the good home for living organisms in the Earth Period after the Information Period.

\section{References}

[1] Portin, P. (2015) A Comparison of Biological and Cultural Evolution. Journal of Genetics, 94, 155-168. https://doi.org/10.1007/s12041-015-0482-4

[2] Chung, D. (2016) The Basic Principles of Kin Instinctive Sociality and Eusociality: Human Evolution. Natural Science, 8, 8-19. https://doi.org/10.4236/ns.2016.81002

[3] Chung, D. (2016) The Human Religious Evolution. Open Journal of Social Sciences, 4, 75-90.

[4] Karlberg, M. (2004) Beyond the Culture of Contest: From Adversarialism to Mutualism in an Age of Interdependence. George Ronald Publisher, Welwyn.

[5] Nisbett, R. (2004) The Geography of Thought: How Asians and Westerners Think Differently....and Why. Free Press, New York.

[6] Yuki, M., et al. (2005) Cross-Cultural Differences in Relationship- and Group-Based Trust. Personality and Social Psychology Bulletin, 31, 48-62. https://doi.org/10.1177/0146167204271305

[7] Larraín, J. (2001) Identity and Modernity in Latin America. Blackwell Publishing, Malden, Massachusetts.

[8] Hamilton, W. (1964) The Genetical Evolution of Social Behavior I. Journal of Theoretical Biology, 7, 1-16. https://doi.org/10.1016/0022-5193(64)90038-4

[9] Hamilton, W. (1964) The Genetical Evolution of Social Behavior II. Journal of Theoretical Biology, 7, 17-52. https://doi.org/10.1016/0022-5193(64)90039-6

[10] Crespi, B.J. and Douglas, Y. (1995) The Definition of Eusociality. Behavior Ecology, 6, 109-115. https://doi.org/10.1093/beheco/6.1.109

[11] Wilson, E.O. (2012) The Social Conquest of the Earth. W. W. Norton \& Company, New York.

[12] White, T.D., et al. (2009) Ardipithecus ramidus and the Paleobiology of Early Hominins. Science, 326, 75-86. https://doi.org/10.1126/science.1175802

[13] Turner, J.C. and Reynolds, K.J. (2010) The Story of Social Identity. In: Postmes, T. and Branscombe, N., Eds., Rediscovering Social Identity: Core Sources, Psychology Press, New York, 13-32.

[14] Cohen, T., Montoya, R. and Insko, C. (2006) Group Morality and Intergroup Rela- 
tions: Cross-Cultural and Experimental Evidence. Personality and Social Psychology Bulletin, 32, 1559-1572. https://doi.org/10.1177/0146167206291673

[15] Shultz, T., Hartshorn, M. and Kaznatcheev, A. (2009) Why Is Ethnocentrism More Common than Humanitarianism? Proceedings of the 31 st Annual Conference of the Cognitive Science Society, 2010-2015.

[16] Hamlin, J.K., Mahajan, N. and Wynn, K. (2013) Not Like Me = Bad Infants Prefer Those Who Harm Dissimilar Others. Psychological Science, 24, 589-594. https://doi.org/10.1177/0956797612457785

[17] McDonald, M. (2012) Evolution and the Psychology of Intergroup Conflict: The Male Warrior Hypothesis. Personality and Social Psychology Bulletin, 32, 15591572.

[18] Herrmann, E., Hare, B., Call, J. and Tomasello, M. (2010) Differences in the Cognitive Skills of Bonobos and Chimpanzees. PLOS ONE, 5, e12438. https://doi.org/10.1371/journal.pone.0012438

[19] Sahlins, M. (1968) Notes on the Original Affluent Society. In: Lee, R. and DeVore, I., Eds., Man the Hunter, Aldine de Gruyter, New York, 85-89.

[20] Dixson, A. and Dixson, B. (2011) Venus Figurines of the European Paleolithic: Symbols of Fertility or Attractiveness? Journal of Anthropology, 2011, Article ID: 569120. https://doi.org/10.1155/2011/569120

[21] Lewis-Williams, D. (2002) The Mind in the Cave: Consciousness and the Origins of Art. Thames \& Hudson, London.

[22] Higham, T, (2014) The Timing and Spatiotemporal Patterning of Neanderthal Disappearance. Nature, 512, 306-309. https://doi.org/10.1038/nature13621

[23] Bloch, M. (2006) Why Religion Is Nothing Special But Is Central. Philosophical Transactions of the Royal Society B, 363, 1499. https://doi.org/10.1098/rstb.2008.0007

[24] Talhelm, T. (2014) Large-Scale Psychological Differences within China Explained by Rice Versus Wheat Agriculture. Science, 9, 603-608. https://doi.org/10.1126/science.1246850

[25] Dunbar, R.I.M. (1992) Neocortex Size as a Constraint on Group Size in Primates. Journal of Human Evolution, 22, 469-493. https://doi.org/10.1016/0047-2484(92)90081-J

[26] Francis, F. (2011) Origins of Political Order: From Prehuman Times to the French Revolution. Farrar, Straus and Giroux, New York.

[27] Francis, F. (2014) Political Order and Political Decay: From the Industrial Revolution to the Globalization of Democracy. Farrar, Strauss, and Giroux, New York.

[28] Mearsheimer, J. (2001) The Tragedy of Great Power Politics. W.W. Norton \& Company, New York.

[29] Bell, D. (2015) The China Model: Political Meritocracy and the Limits of Democracy. Princeton University Press, Princeton, NJ. https://doi.org/10.1515/9781400865505

[30] Fukuyama, F. (1992). The End of History and the Last Man. Free Press, New York.

[31] The Economist Intelligence Unit (2016) Democracy Index 2015: Democracy in an Age of Anxiety. http://www.yabiladi.com/img/content/EIU-Democracy-Index-2015.pdf

[32] Momani, B. (2015) Arab Dawn: Arab Youth and the Demographic Dividend They Will Bring. University of Toronto Press, Toronto, Canada.

[33] Wright, R. (2013) Imagining a Remapped Middle East. The New York Times, Sep- 
tember 28 .

[34] De Botton, A. (2012) Religion for Atheists: A Non-believer's Guide to the Uses of Religion. Hamish Hamilton, London.

Submit or recommend next manuscript to SCIRP and we will provide best service for you:

Accepting pre-submission inquiries through Email, Facebook, LinkedIn, Twitter, etc. A wide selection of journals (inclusive of 9 subjects, more than 200 journals)

Providing 24-hour high-quality service

User-friendly online submission system

Fair and swift peer-review system

Efficient typesetting and proofreading procedure

Display of the result of downloads and visits, as well as the number of cited articles Maximum dissemination of your research work

Submit your manuscript at: http://papersubmission.scirp.org/

Or contact jss@scirp.org 